\title{
口腔内溗気性菌の研究
}

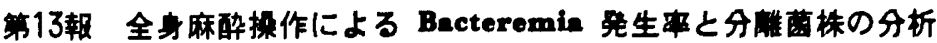

\author{
森本仰・五井健三
}

\section{Studies on anaerobic organisms in the oral cavity}

\section{Incidence of bacteremia following oro-and ansotracheal intubation and analyals of the isolated organisms}

\author{
Shin Morimoto - Kenzo TamaI
}

緒

E

transient bacteremia が種々の原因から惹起され，心 内膜炎など臨床的に重䉆な症状がひき起こされることは すでに知られている，これらの原因が特に口腔領域ある いは泌尿器科領域の手術操作および娭查操作によって起 こされることも衆知の事実である。このため従来から口 腔外科頋域において，抜域術後およびその他の口腔外科 手術後に発生する transient bacteremiaについての研究 は数多くなされ，その起因菌の由来についても转多の研 究がなされている1〜4).

一方，近年全身麻醉の頻度が多く，気管内麻䣲の增加 に伴い術後合併症として, 肺炎, 膿胸, 肝膿掦, 肺虚 脱, 肺塞栓, 胸膜炎などの major respiratory complications と, 咳, 咽頭炎, 喉頭炎, 気管支炎, 気管炎, 吃 逆などの minor respiratory complications の症例かi増 加していることが報告ら)され，これらの原因として麻舅 の挿管および抜管時の機械的な操作が口腔，萛腔あるい は咽頭, 声带付近の常在菌が持ち込まれることがその主 因と考えられている。

われわれは，口腔内嫌気性菌の研究を主題とした一連 の研究の中で, 口腔外科手術後に発生する transient bacteremia が単に術野感染ばかりでなく，麻酔操作時 にすでに発生しているのではないかと考え，従来から使 用している玉井・福田培地 ${ }^{6)}$ (以下 T.F medium と略

金沢大学医学部付属病院歯科口腔外科（主任：玉井 健三教授)

Clinic of Dento-Oral Surgery, School of Medicine, Kanazawa University (Chief: Prof. Kenzo Tamai) 受付日：昭和52年 9 月 9 日
す）を用いて挿管直後の transient bacteremia の発生を 検索したのでその概要について㫰告する。

\section{実 梌 方 法}

実暂対象例：金讯大学医学部付属病院科口腔外科の 入院患者の5ちで，前投蒋として抗生物質，および消炎 醅素绪を全く使用せず，全身麻醉下で口腔外科手術を行 った 113 症例を対象とした。

使用培地：口腔内渞気性菌分離培地として従来から routine work に使用している $\mathrm{T} \cdot \mathrm{F}$ medium を全量 $30 \mathrm{ml}$ の culture bottle K注入し、 オムキ+ップで密封後, 吸 引し，队部を陰圧とした自家製 culture bottleを使用し た.

材料採取法：麻酥医による全身麻㮣の intubation 完 了後，10分以内に患者の前腕または下肢の採血部をボピ トンョート原液で消毒後，さらに $0.4 \%$ ヒビテン・グリ コネート容液で消毒し, 静脈血を娍菌注射器で約 $3 \mathrm{ml}$ 採血し，ただちに T.F 処方の自家製 culture bottle(全 量 $30 \mathrm{ml}$ ) に注入後, $37^{\circ} \mathrm{C} \cdot 7$ 日間培養した。

細菌分離法: 採血, 移植後， $37^{\circ} \mathrm{C}$ で 7 日間培養し， 培養增菌したものを $\mathrm{T} \cdot \mathrm{F}$ 血液寒天平板培地に塗沫し, $37^{\circ} \mathrm{C} \cdot 2$ 日間嫌気培養した。培養後, 平板上に形成して きた集落を $\mathrm{T} \cdot \mathrm{F}$ 液状培地（全量 $4 \mathrm{ml}$ ) に釣菌し, $37^{\circ} \mathrm{C}$ - 2 日間増菌した，増菌後 $\mathrm{T} \cdot \mathrm{F}$ 血液寒天平板培地へ心 たたび蕀沫し，好気的および嫌気的に培湌し colony isolationを行ったのち形成してくる集落を釣菌し，増 菌・培養したものを純粋分離菌株とした，その分離菌株 について同定および薬剤感受性試験を施行した。

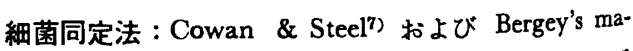
nual ${ }^{8)}$ に従って同定した. すなわち好気性菌群について 
は Cowan \& Steel に, 嫌気性菌群では Cowan \& Steel から同定し，不借な点については Bergey's manual に従って同定した.

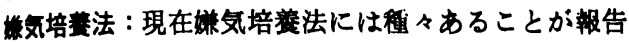
されているが，臨床上さわめて routine work にできる ピロガロール・無水炭酸ソーダ法りで果眕を施行した。 その祭，飽和重曹水を使用したか，これは無芽泡媒気性 菌の発育を促進するといら上野 ${ }^{10)} ら の$ 報告に従ったもの である.

莱戍感受性試験：使用薬剂は栄研三灌度ディスクの 9 都について央験した。 すなわち，Penicillin (PCG)， Aminobenzyl Penicillin (ABPC), Cephaloridine(CER) Cephalothin (CET), Chloramphenicol (CP), Tetracycline (TC), Erythromycin (EM), Oleandomycin (O M), Clindamycin (CLDM) の計 9 绪について分離菌株 の薬訪感受性を検討した，薬剤感受性の判定は好気性菌 では, $37^{\circ} \mathrm{C} \cdot 24$ 時間培養後, 嫌気性菌では $37^{\circ} \mathrm{C} \cdot 48$ 時間 培湌後形成されてくる阻止円の有無により(卅)，(卅）, (十)，(-)の 4 段階に分類し，臨床的に(H)，（H）を蒋 削感受性，(十)，（一)を薬绪耐性として総合判定した。

\section{実 験 成 績}

\section{年粭・性別による Bacteremia}

経鼻・経口捜管症例を，年踰および性別によって bacteremia の発生率を分析した。 その結果は表 1 ・表 2に示すごとく，跬算拝において51藏以上で䄪50\%の 高い bacteremia の発生を認めた。 しかし経口挿管にお いては，症例数も少なくて分析の対象とはならないが年 踰によって bacteremia の発生率に著変は認められな かった，一方，経軎・経口とも女性が男性の䄪 2 倍の bacteremia 発生を認めた。

\section{括管法による Bacteremia 発生率}

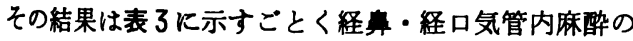
择管直後に 113 症例中 38 应例， $33.6 \%$ の bacteremia の

\section{表 1 年龄・性別に上る菌血症（释鼻插管）}

\begin{tabular}{c|c|c|c}
\hline \multicolumn{1}{c|}{ AGE } & M & \multicolumn{1}{|c|}{ F } & Total \\
\hline $0-10$ & $1(0)$ & $1(0)$ & $2(0)$ \\
$11-20$ & $2(0)$ & $6(3)$ & $8(3)$ \\
$21-30$ & $10(2)$ & $10(2)$ & $20(4)$ \\
$31-40$ & $5(1)$ & $3(2)$ & $8(3)$ \\
$41-50$ & $7(1)$ & $12(5)$ & $19(6)$ \\
$51-60$ & $7(3)$ & $6(3)$ & $13(6)$ \\
$61-$ & $5(2)$ & $5(3)$ & $10(5)$ \\
\hline Total & $37(9)$ & $43(18)$ & $80(27)$ \\
\hline
\end{tabular}

( ) : No. of bacteremia positive cases

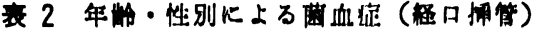

\begin{tabular}{c|c|c|c}
\hline AGE & M & F & Total \\
\hline $0-10$ & $2(1)$ & & $2(1)$ \\
$11-20$ & $3(1)$ & & $3(1)$ \\
$21-30$ & $7(0)$ & $5(4)$ & $12(4)$ \\
$31-40$ & $2(1)$ & $1(1)$ & $3(2)$ \\
$41-50$ & $3(1)$ & $3(1)$ & $6(2)$ \\
$51-60$ & & $2(1)$ & $2(1)$ \\
$61-$ & $3(0)$ & $2(0)$ & $5(0)$ \\
\hline Total & $20(4)$ & $13(7)$ & $33(11)$ \\
\hline \multicolumn{3}{r}{} \\
\hline
\end{tabular}

表 3 全身麻酔拆管法による菌血症発生率

\begin{tabular}{c|c|c|c}
\hline Method & Total cases & $\begin{array}{c}\text { No. of } \\
\text { positive cases }\end{array}$ & $\begin{array}{c}\text { Ratio } \\
(\%)\end{array}$ \\
\hline nasotracheal int. & 80 & 27 & 33.9 \\
orotracheal int. & 33 & 11 & 33.3 \\
\hline Total & 113 & 38 & 33.6 \\
\hline
\end{tabular}

発生を認めた．さらに経算・経口捜管法について分析し てみると，経算挿管では 80 症例中 27 症 例， $33.9 \%$ に bacteremia を珰め, 経口挿管では33店例中11应例, 33. 6\% に認められ，挿管法による bacteremia 発生率に有意の 差を認めなかった。

\section{分離菌株}

bacteremia 陽性症例から分離された菌株は表 4 のご とく，嫌気性菌群において14菌株分離され，そのうち Propionibacterium acnes か; 9 菌株とその主体をなし, 好

表 4 分離菌株

\begin{tabular}{l|c}
\hline Aerobic Organisms & No. of strains \\
\cline { 2 - 2 } Staphylococcus epidermidis & 15 \\
Staphylococcus aureus & 5 \\
Corynebacterium & 4 \\
Bacillus brevis & 4 \\
Streptococcus haemolyticus & 1 \\
Actinobacillus & 1 \\
Flavobacterium & 1 \\
Gram(-) rod & 1 \\
Anaerobic Organisms & \\
Propionibacterium acnes & 9 \\
Peptococcus & 2 \\
Lactobacillus lactis & 2 \\
Bacteroides & 1 \\
\hline Total & 46 \\
\hline
\end{tabular}




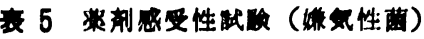

\begin{tabular}{l|c|c|c|c|c|c|c|c|c}
\hline \multicolumn{1}{c|}{ Organisms } & PCG & ABPC & CET & CER & CP & TC & EM & OL & CLDM \\
\hline Propionibacterium & $8 / 9$ & $8 / 9$ & $9 / 9$ & $9 / 9$ & $2 / 2$ & $9 / 9$ & $9 / 9$ & $5 / 5$ & $6 / 7$ \\
Peptococcus & $1 / 2$ & $1 / 2$ & $1 / 2$ & $1 / 2$ & $2 / 2$ & $2 / 2$ & $2 / 2$ & $2 / 2$ & $2 / 2$ \\
Lactobacillus & $1 / 2$ & $1 / 2$ & $1 / 2$ & $1 / 2$ & $2 / 2$ & $2 / 2$ & $2 / 2$ & $2 / 2$ & $2 / 2$ \\
Bacteroides & & & & & & & & & \\
\hline Total & $10 / 13$ & $10 / 13$ & $11 / 13$ & $11 / 13$ & $6 / 6$ & $13 / 13$ & $13 / 13$ & $9 / 9$ & $10 / 11$ \\
$\%$ & 76.9 & 76.9 & 84.6 & 84.6 & 100.0 & 100.0 & 100.0 & 100.0 & 90.9 \\
\hline
\end{tabular}

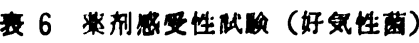

\begin{tabular}{l|c|c|c|c|c|c|c|c|c}
\hline \multicolumn{1}{c|}{ Organisms } & PCG & ABPC & CET & CER & CP & TC & EM & OL & CLDM \\
\hline St. epidermidis & $4 / 15$ & $5 / 15$ & $14 / 15$ & $15 / 15$ & $10 / 10$ & $13 / 15$ & $11 / 15$ & $8 / 12$ & $4 / 5$ \\
St. aureus & $2 / 5$ & $2 / 5$ & $5 / 5$ & $5 / 5$ & $3 / 3$ & $4 / 5$ & $5 / 5$ & $3 / 3$ & $2 / 2$ \\
Bacillus & $1 / 4$ & $1 / 4$ & $1 / 4$ & $2 / 4$ & $3 / 3$ & $4 / 4$ & $4 / 4$ & $4 / 4$ & $1 / 1$ \\
Corynebacterium & $4 / 4$ & $4 / 4$ & $4 / 4$ & $4 / 4$ & $2 / 2$ & $4 / 4$ & $3 / 4$ & $2 / 2$ & $1 / 2$ \\
Streptococcus & & & & & & & & & \\
Actinobacillus & & & & & & & & & \\
Flavobacterium & & & & & & & & & \\
Gram(-)rod & & & & & & & & & \\
\hline Total & $11 / 28$ & $12 / 28$ & $24 / 28$ & $26 / 28$ & $18 / 18$ & $25 / 28$ & $23 / 28$ & $17 / 21$ & $8 / 10$ \\
$\quad \%$ & 39.3 & 42.9 & 85.7 & 92.9 & 100.0 & 89.3 & 82.1 & 81.0 & 80.0 \\
\hline
\end{tabular}

気性菌群では32菌株中 Staphylococcus epidermidis かi15 菌株と約半数を占めており，好気性菌,嫌気性菌ともグ 么陽性菌が非常に高く検出された。 その他 Peptococcus Lactobacillus が各 2 株分離されたが，最近各科領域で非 常に問題となっているグラム陰性嫌気性桿菌Bacteroides が挿管後の bacteremia から分離された.

一方, Staphylococcus epidermidis のほかに好気性菌 群では Staphylococcus aureus が 5 株, Corynebacterium Bacillus が各 4 株分離された。

\section{嫃気性菌感染率}

bacteremia より分離された嫌気性菌は 46 菌株中 14菌 株で，嫌気性菌感染率は $30.4 \%$ と比較的高く関与してい る成績を得た。

\section{分離菌株の薬郕感受性試検}

表 5 ・6に示すごとく嫌気性菌群では，PCG，ABPC が76.9\%と感受性が低いが， CP，TC，EM， OL では 100\%の感受性を示し耐性菌の少ない結果が得られた.一 方, 好気性菌群においては CET, CER, CP, TC, EM, OL, CLDM の 7 剂において 80\% 以上の高い感受性を 示したが， PCG，ABPC では 40\% 前後の低い感受性を 示し耐性菌を認める結果が得られた。

\section{考按}

気管内麻䣲時，チューブによる粘膜損侮，口腔咽頭璌 内あるいは声門付近の細菌の気道内への持ち込みによる 咽頭・喉頭炎, 気管支炎, 柤水董, 肺炎など術後合併应 は臨床上きわめて身近でかつ重要な問題となっている. 一方, 従来注意されなかった挿管・拔管後の transient bacteremia がほかの transient bacteremia 同様, 重篤 な症状を呈してくることは咟床上非常に重大なことであ る. すなわち, 従来全身麻䣲後の発熱などの症状は当然 のものとして主治医は対処してきたか，挿管操作による transient bacteremia によるものであるならば，たとえ 一過性のこととはいえ患者にとってはきわめて重要なこ とであり，術者としてもこれらの苦痡を除去することが いかに重要であるかがわかるだろら。

口腔外科領域では, Simon と Goodwin ら ${ }^{11)}$ が抜齿 後に生じた bacterial endocalditis の case reportによっ て初めてロ腔内 Streptococcus viridans と bacterial endocarditis との関係を証明して以来, transient bacteremia が臨床的に注目を浴びることになった.

今回の実験結果から，気管内麻醉挿管直後に释基で は，80症例中27症例の33.9\%に，経口では33症例中11症 
例の33.3\%に bacteremia が比較的高率で認める成緹を 得たことは，心疾患などの基礎疾患をむつ㤁者の手術に 㗨してはきわめて重大なことであり、術後のbacteremia から septicaemia に経過する危険性を多分に考えなけれ ばならない。

Berry ら ${ }^{12)}$ は，声带を直視し非外传性に括管を行った 释口25例，経算25例の気管内麻酔例について bacteremia の検索を行い, 経口では bacteremia の発生を認めず経 真ではわずかに 4 例(16\%)に bacteremia を梕めたと悢 告している，両者を比較してみると，われわれの成筫で は経算・释口とも約 $34 \%$ と高い bacteremia 発生率を認 め，挿管法による差異を認めなかったが，その原因とし て医学部付属病院の性格上, 麻酔研攸医の教育のために blind technique を試み不可能な場合のみ声带を直視し て挿管する例が多いためであると考える.

一方，起因菌の由来について文献上考察してみると， 浅井ら ${ }^{13)}$ は，口腔咽頭内に棲息する細菌数を調へ，術後 の気道感染との関連を研究し34例中13例に術後肺合併症 を認め, Neisseria, Citrobacter がその主因菌で挿管によ る細菌の気管内持ち込みが原因であろらと報告してい る. また天方ら ${ }^{14)}$ は，気管内麻酔に始まると考えられる 乎吸感染の起炎菌を早期に決定する目的で気管内麻酔実 施下の回路内遊離細菌を捕捉し，その細菌学的検索を行 った報告をしている。すなわち，挿管直前の声帯擦過材 料の12症例中 4 例に菌株を認め, 搬管直後では12症例中 全症例に菌株の検出を認めており，それらは $\alpha$-Streptococcus 9 例, Neisseria か; 6 例, Staphylococcus epidermidis かi 3 例, Staphylococcus aureus が 3 例であった と報告している.これらの口腔咽頭領域に存在する normal flora $の$ bacteria が㨉管操作時の外傷により容 易に血中へ入り込むことは十分考察される.

Lefrock $ら^{15)} は$, nasotracheal suction 後の bacteremia を健康学生群 (control) と入院患者群とで比較し, 前群 で1/30(0.33\%), 後群で12/68(17.6\%)に bacteremia の 発生を認め, 菌株が nasopharyngeal から採取したもの と同一菌種であったことより traumatic procedure との 烕係が深く, normal flora の菌株が楀咽頭粘膜の損侮に より血中に入り込むものと, trachea に押し込まれた菌 朱が容易に vascular mucosa を通して侵入するからた と結論つけている。今回われわれの実験では, 口腔界腔 咽頭の常在菌である Staphylococcus epidermidis, Staphylococcus aureus, Corynebacterium, Bacillus などの 好気性菌群と, Propionibacterium, Peptococcus, Lactobacillus などの嫌気性菌群が多数検出され，挿管直後の transient bacteremia は normal flora の菌株が深く関 与しているものと考え, Lefrock らの主張と同意するも のである.

前気性菌分麇率は bacteremia より分離された46菌株 中14菌株で30.4\%とかなりの高い分離率を示し，插管直
後の transient bacteremia に嫌気性泳がきか力て房く

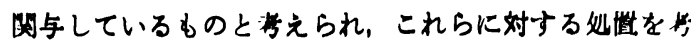
えておかなければならない。

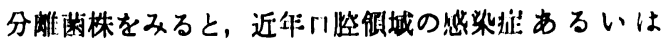
bacteremia から病原性が留しいことで注目を浴びてい ろ Propionibacterium, Peptococcus, Lactobacillus など のクラム陽性菌がその大半を占めたが，他科颃㳦で免疝

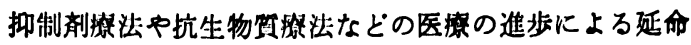
とともに、いわゆる Opportunistic infection, Superinfection あるいは Suprainfection としての挽聅忠を 有するものへの末期感染の bacteremia の䏴加として恰 出されるグラム陰性桿菌である Bacteroides む1例であ るが，㸾めた点は注目に值する。

分潅菌株の蒋绪惑受性試験については，嫌気性菌群に おいては感受性がきわめて高く，従来から報告されてい る成績と一致する ${ }^{16)}$ しかしながら Peptococcus, Lactobacillus では PCG, ABPC, CET, CER と 4 剂耐性を 衿めたことは嫌気性菌においても多剂耐性菌が増加しつ つあることを示唆するもので，臨床上十分注意していか なければならない。

好気性菌では PCG, ABPC に耐性菌の增加を認め, そのほとんどが Staphylococcus であった。

このよ5に bacteremia が高率で発生することからそ の予防を目的として，抗生物質を投与した報告が多数報 告 ${ }^{17,18) さ れ て い る . ~}$

特に, 先天性, 後天性心疾患の患者に対してはbacterial endocarditis になる素因が高いので, American Heart Association's は歯科処置における抗生物質の投与による 予防について提唱している19)

以上のことより，気管内麻酔操作による bacteremia の予防には，抗生物質の有効血中濃度，組織内濃度が重 要であり，かつ術前の抗生物質投与には術後の bacteremia を考虑して抗生物質の選択を決定すべきである.

\section{結語}

気管内麻酔 113 症例を対象に插管直後に発生する bacteremia の検索をした結果, 次のよらな結論を得た。

1) 経算・経口㨉管ともに女性の感染率が高い

2）経其・䅅口抻管による bacteremia の発生率は約 $34 \%$ である。

3）全身麻醉挿管法による bacteremia の発生率に有 意差は認めない.

4 ） bacteremia から分離される菌株は，Staphylococcus epidermidis (好気性菌), Propionibacterium acnes （嫌気性菌）が約50\%を占めた.

5 ）挿管時の嫌気性菌感染率は約30\%である.

6 ）感受性試験の結果，術前投与は TC が望ましい と結論した。 
本渝交の要旨は，昭和52作５月，第13可日本口㓐科学

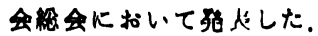

\section{文 虍}

1) Cobe, H.M.: Transitory bacteremia. Oral Surg 7: 6091954.

2) ('rawford, J.J., et al.: Bacteremia after tooth extractions studies with the aid of produced anacrobically sterilized culture media. Appl Microbiol 27: 9271974.

3) Kraut, R.A., et al.: Bacterial endocarditis of dental origin. J Oral Surg 34: 10311976.

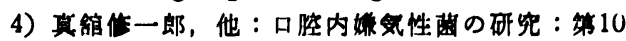
報口腔外科手得後の bacteremia，日口外部 22: 2691976.

5) Gillespie, N.A., et al.: Endotracheal anesthesia. The relation of Nasotracheal and orotracheal intubation to respiratory morbidity Endotra Anesth 2: 281941.

6）玉井健三，他：口腔内嫌気性菌の研究。第一報 分離培地の㭘尌. 口科誌 19：495 1970.

7) Cowan, S.T., et al.: Manual for the identifcation of medical bacteria. ed 2, Cembridge Univ Press London, 1975, p 1.

8) Buchanan, R.E., et al.: Bergey's manual of detaminative bacteriology. ed 8 , Williams \& Wilkins Co, Baltimore, 1974, p 1.

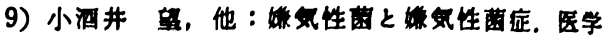
散㹣，京京，1968，41面。

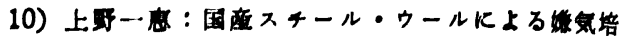

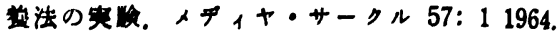

11) Simon, D.S., et al.: Should good teeth be extracted to prevent Streptococcus viridans endocarditis ? Lancet 1: 12071971.

12) Berry, F.A., et al.: A comparison of bacteremia occuring with nasotracheal and orotracheal intubation. Anesth \& Analg 52: 8731973.

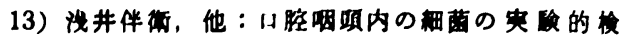

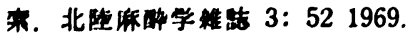

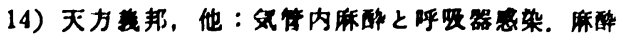
15: 12091966.

15) Lefrok, J.L., et al.: Transient bacteremia associated with nasotracheal suctioning. JAMA 236: 16101976.

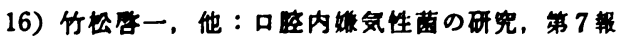

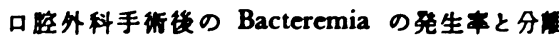

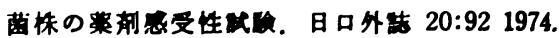

17) Shirger, A., et al.: Bacterial invation of the blood following surgical procedure J Lab C. in Med 55: 3761960.

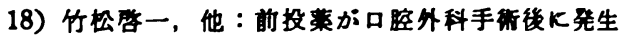
する bacteremia Kおよほす影密. 日外誌 21: 3901975.

19) American Heart Association: Prevention of bacterial endocarditis. New York, American Heart Association, 1972, p 2. 